\title{
Implementation of Linguistic Politeness throughout Online Lectures via WhatsApp during the Covid-19 Pandemic
}

\author{
*Nur Ihsan Halil, Takwa, Musliha \\ Indonesian Language Education Study Program, Faculty of Teacher Training and Education, \\ Universitas Sembilanbelas November Kolaka. Jl. Pemuda No. 339, Kolaka 93517, Indonesia \\ *Corresponding Author e-mail: nurihsan6411@gmail.com
}

Received: June 2021; Revised: September 2021; Published: November 2021

\begin{abstract}
This research aims to investigate the implementation of politeness in the language of lecturers and students as well as students and students through online lectures at the Faculty of Teacher Training and Education, Universitas Sembilanbelas November Kolaka on the WhatsApp application. The research methodology used is descriptive qualitative with a focus on research, namely the fulfillment and violations of the principles of politeness in the language contained in online lecture conversations on WhatsApp. The data collection technique uses documentation or screenshots, and the data analysis technique uses content analysis methods with inductive procedures. The results indicate that the communication of lecturers to students and students to students based on the WhatsApp social network still pays attention to the principles of linguistic politeness in communication discourse. Based on the WhatsApp social network, students and lecturers can meet the principles of linguistic politeness, including maxim of wisdom, generosity, appreciation, simplicity, compatibility, and sympathy. However, there were also still some violations of the principle of politeness.
\end{abstract}

Keywords: Covid-19; Linguistic politeness; Online Lectures; WhatsApp

How to Cite: Halil, N. I., Takwa, \& Musliha. (2021). Implementation of Linguistic Politeness throughout Online Lectures via WhatsApp during the Covid-19 Pandemic. Jurnal Penelitian Dan Pengkajian Ilmu Pendidikan: E-Saintika, 5(3), 195-211. https://doi.org/10.36312/esaintika.v5i3.484

\section{INTRODUCTION}

The world is facing a global problem, namely the Corona Virus Disease (COVID19) outbreak, better known as the Corona Virus. The Covid-19 outbreak in Indonesia has spread to various regions. Jabodetabek became the epicenter of the spread of the virus so that it spread throughout Indonesia. The government imposed social distancing, and several regions imposed Large-Scale Social Restrictions (PSBB) to break the chain of the spread of Covid-19. These policies impact almost all sectors of life, including the education sector. Through the Minister of Education and Culture, the government decided to move the face-to-face learning process to online learning, which was announced through Circular Number 36962/MPK.A/HK/2020. Thus, online learning is applied to all levels of education. According to Damhuri et al. (2018), the disease can affect humans and organisms. According to Anhusadar (2020), Thelwall \& Thelwall (2020) Covid-19 affects the educational process with full online learning and blended learning. According to Thornton (2020), less contact with others 
effectively reduces the Covid-19. According to Khasanah et al. (2020), online learning and study from home are the best ways to reduce Covid-19 in Indonesia.

Contextual learning is a learning concept that links learning materials with everyday life. Students are expected to discover and develop new knowledge and skills following the knowledge they have Nurdin et al. (2017). Contextual learning is a concept that helps teachers make connections between materials and encourage students to make connections between their knowledge and the application of attitudes (Nurhadi, 2005). It is carried out daily by involving the six components of effective learning: constructivism, asking questions, discovering, learning communities, capital, and authentic assessment. Contextual learning connects knowledge and students' daily activity, so they understand and learn more meaningfully (Agustiani et al., 2020; Jahring et al., 2020). According to Hunaidah et al. (2019), students taught using the discovery model have skills better than conventional learning, because it can improve students' mastery of concepts. According to Damhuri et al. (2018), Harianto et al. (2019), HL et al. (2020), Sejati et al. (2020), contextual learning give matter or issue and direct observation that it is in the surrounding students' environment which can make students easy to understand.

Although the learning process is carried out online, character education is still important and cannot be ignored in the education sector. According to Sukariasih, Sahara, et al. (2019), the curriculum 2013 has three domains: attitude, knowledge, and skill. The main purpose of education is to make students smart in terms of intellectual and good character (Djidu \& Retnawati, 2018). In line with Law Number 20 Year 2003 on National Education System, Rukiyati (2019) the purpose of national education is to develop Indonesian people and educate the life of the nation, Humans who have piety and faith in God almighty and have noble character, are independent, strong personalities, spiritual and physical health, skills and abilities. knowledge, and finally have a sense of responsibility for the nation and society. Sujana (2019) also explains that the purpose of National Education is to develop capabilities and shape the character and civilization of a dignified nation in the context of educating the nation's life. It aims to develop the potential of students to become human beings who believe and fear God Almighty, have noble character, healthy, knowledgeable, capable, creative, independent, and become a democratic and responsible citizen. This goal must still be carried out regardless of the learning method used, both conventional and online learning. According to Nursalam et al. (2019), Sejati et al. (2016) character is in the affective domain that affects students in the classroom and living environment.

As facilitators in teaching and learning activities, educators have broader social experiences to shape students' character (Kusmana, 2011). This is explained in Emda (2017) Government Regulation Number 19 Year 2005, in article 28, paragraph 3 which states that what is meant by social experience or social competence of educators is the ability of educators as part of the community to communicate and interact effectively with students, fellow educators, staff education, parents or guardians of students and the surrounding community. This is because characters are considered not to be formed automatically but are developed through learning (Sejati et al., 2017). This means that educators are in charge of developing the character of these students through learning. According to the Ministry of Education and Culture, there are 18 values of character education, one of which is the value of character education which focuses on the attitude of responsibility, namely an attitude and behavior of students 
to carry out their duties and obligations, which they should do, to themselves, society, the environment (nature, social and environmental). culture), the state and God Almighty.

Education experts agree on the importance of improving character education through education (HL et al., 2020). For this reason, when online learning takes place, educators must still pay attention to the stages of the learning process. For example, giving greetings before the learning process occurs or providing a stimulus in the form of motivation to students before continuing with the online learning process (Apuke \& Iyendo, 2018). According to Kasmiati et al. (2020), Nursalam et al. (2019), Sejati et al. (2017), education processes and characters that are covered in the National Curriculum can be obtained by students permanently, then transmitted in daily activity in their community. According to Akhfar \& Saputra (2020) Learning must be interesting and fun in terms of psychology students, because it requires an enabling learning approach students to actively build cognitive ability to understand lessons so that the lessons he learns can last a long time and can improve the student's abilities/skills.

The online learning system is implemented through a personal computer (PC), laptop, or mobile phone connected to an internet network. Teachers can learn together simultaneously using groups on social media such as WhatsApp, Telegram, Instagram, Zoom applications, or other media as learning media. That way, the teacher can ensure that students take part in learning simultaneously, even though in different places. However, in the application of online learning, some limitations are critical. Students who do not have cellphones are confused (Supariani et al., 2021). According to Saifuddin (2018) laptop or smartphone is the required instrument in elearning.

The solution to this problem is that the government provides policies by opening free online application services and providing free internet quotas. The government must also prepare an online-based learning curriculum and syllabus. For schools, it is necessary to conduct online technical guidance on the online implementation process and conduct socialization to parents and students through print media and social media about the procedures for implementing online learning, its relation to its roles and duties, and improving network connections in remote villages. According to Anhusadar (2020) internet connection around students' home is the main point handled by the government and schools.

WhatsApp is one of media can be applied in e-learning. WhatsApp with the Group feature enables to post the matter in text, picture, audio, and video. Then lecture and students can interact with one and another. According to Halil (2020), WhatsApp is the best learning supplement and complement media. According to Putria et al. (2020), WhatsApp provides the matter and assignment upload and then its comment between teacher and students.

The teaching material in WhatsApp is uploaded in the attachment and the photo or microphone icon. The material is in the form of asynchronous learning. The synchronous is in a video call, but it is limited to 4 members. All matter files are available, such as Microsoft PowerPoint, Microsoft Word, Microsoft Excel, jpeg, Pdf, MP3, and MP4. According to Khasanah et al. (2020) WhatsApp Group is the Application that can explain the matter in the learning process. According to Putria et al. (2020), the matter in WhatsApp learning gives and control by the teacher. 
The student role in WhatsApp learning is as a subject of learning. The student's grew their knowledge when they were a process of learning in the chat room. The teacher's role is to facilitate the student to construct their knowledge. According to Wibawa et al. (2019) the teacher role in the mobile phone online learning gives direction, guided instruction, and stimulating students' activeness.

Another thing that is important to note is the use of the teacher's language to students in delivering learning materials, educators are required to use polite language as learning is done conventionally as well as students in responding to educators during the online learning process. When students and the lecture interact in WhatsApp, a chat activity contains the language character. According to Hidayati. et al. (2017), Sejati et al. (2017) politeness is one of character could be seen in the direct and indirect language use in the learning process. According to Saputra (2020), in the implementation of learning in the classroom, the teacher's material has made students full of preconceptions of the material. However, teachers are often not aware of students' preconceptions, nor are the students themselves. This indication emphasizes that the teacher must first know what concepts students already have before explaining new material or concepts, even though in reality, the concepts to be explained are not yet fully known or even different from those understood by students.

Certainly, keep in mind that the learning process in the classroom is very much different from the online learning process. One of the most significant differences lies in the use of the language of educators and students in interacting to carry out the online lecture. The use of language in delivering lectures online remains in the context of the principles of linguistic politeness, even if lectures are connected with online applications or not. The politeness in the language shows awareness of dignity, both spoken and written. According to Sejati et al. (2019), the interaction between students and teachers in the learning process must be polite. According to Rahmawati (2016), the teacher must control student comments in the discussion section in e-learning.

This is one of the reasons why the researchers research linguistic politeness through online lectures, especially at the Faculty of Teacher Training and Education, Universitas Sembilanbelas November Kolaka (USN Kolaka) during the Covid-19 Pandemic. It is in line with the policy of the Chancellor of the USN Kolaka through Circular Letter Number 488/UN56/SE/2020 regarding the implementation of the Tri Dharma of Higher Education during a pandemic which requires every lecturer to create a WhatsApp group for every subject taught and conduct online learning activities. WhatsApp Web-based starting on June 8, 2020 until the end of the Covid-19 pandemic. According to Hassan \& Ahmed (2018), Prajana (2017), WhatsApp in the learning media in e-learning can help in the learning process.

This matter becomes very important because during the implementation of online lectures at the Faculty of Teacher Training and Education, USN Kolaka, researchers found that the conversion process between lecturers and students in the WhatsApp application contained some impolite conversations spoken by students to lecturers and vice versa.

\section{METHOD}

This research is research-based on a qualitative paradigm, with content analysis techniques and inductive procedures. This research was conducted on the USN Kolaka at the Faculty of Teacher Training and Education with data collection 
techniques using documentation. The data documented are conversations on Whatsapp, which collected as many as 85 fulfillment data from three study programs. They were the Indonesian Language Education Study Program, the Physics Education Study Program, and the Geography Education Study Program. It consisted of six maxims of linguistic politeness and 7 violations. Data analysis used content analysis techniques and inductive procedures. This means that the data obtained are then grouped into categories that have been previously applied. These categories were revised and verified through the analysis process. The criteria for meeting politeness in language use indicators of meeting politeness in the language (Scott, 2008).

The validity test used in this study is pragmatic validity, which is to see how far the data that can be analyzed is appropriate in speech. The reliability test in this study uses an intra-rater reliability test, which means reading and examining the object repeatedly until it gets the data in question. As Moleong (2014) explained, this reliability test requires the persistence of the researcher's observations. In addition, an inter-rater reliability test is also used, namely discussing research results with colleagues who are considered to have good intellectual abilities and linguistic capacity.

Table 1. Indicators of Compliance with the Principles of Language Compliance (Leech, 2014)

\begin{tabular}{|c|c|c|c|}
\hline No & Maximal & Indicator & Sub-indicator \\
\hline 1 & Wisdom & $\begin{array}{l}\text { - } \text { Common sense } \\
\text { - Wise } \\
\text { - Competent } \\
\text { - } \text { Be careful }\end{array}$ & $\begin{array}{l}\text { - Offer something that benefits others } \\
\text { - Offers with positive results in the form of } \\
\text { profits for objects or materials, good } \\
\text { names, achievements, awards, and } \\
\text { comfort to others. } \\
\text { - Using an indirect strategy not to demand } \\
\text { a direct response in the form of the } \\
\text { actions of others which can be in the form } \\
\text { of suggestions, advice, or impositivity } \\
\text { - Using interrogative sentences to express } \\
\text { a command } \\
\text { - Provide a piece of information that does } \\
\text { not harm others. }\end{array}$ \\
\hline 2 & Generosity & $\begin{array}{l}\text { - Generous } \\
\text { - Helpful } \\
\text { - Full of Sacrifice } \\
\text { - Submissive }\end{array}$ & $\begin{array}{l}\text { - Make a flexible offer to others } \\
\text { - Giving something that produces an effect } \\
\text { in the form of one's own actions, for } \\
\text { example, giving a good prayer. } \\
\text { - Doing something that produces an effect } \\
\text { in the form of one's actions (in the } \\
\text { impositive illocution) which can be in the } \\
\text { form of being caring and generous } \\
\text { - Be helpful and respectful of others by } \\
\text { giving good advice or advice }\end{array}$ \\
\hline 3 & Appreciation & $\begin{array}{ll}\text { - } & \text { Sincerely } \\
\text { - } & \text { Noble } \\
\text { - } & \text { Helpful } \\
\text { - } & \text { Thankful }\end{array}$ & $\begin{array}{l}\text { - Give sincere compliments to others that } \\
\text { can be in the form of admiring, } \\
\text { respecting, and not condescending } \\
\text { - Giving appreciation to others } \\
\text { - Don't say unpleasant things to others } \\
\text { - Not insulting, criticizing, and slandering } \\
\text { others }\end{array}$ \\
\hline
\end{tabular}




\begin{tabular}{|c|c|c|c|}
\hline No & Maximal & Indicator & Sub-indicator \\
\hline 4 & Simplicity & $\begin{array}{l}\text { - } \text { Only } \\
\text { - Straightforward } \\
\text { - Standard } \\
\text { - }\end{array}$ & $\begin{array}{l}\text { - Shows one's own weakness; Be humble } \\
\text { and reduce self-praise } \\
\text { - Don't show off your strengths to others } \\
\text { - Don't brag about your knowledge }\end{array}$ \\
\hline 5 & Compatibility & $\begin{array}{l}\text { - } \text { Agreed } \\
\text { - } \text { Corresponding } \\
\text { - } \text { Suitable } \\
\text { - } \text { In harmony }\end{array}$ & $\begin{array}{l}\text { - Maximizing agreement or agreement } \\
\text { between oneself and others by providing } \\
\text { opinions that can be accompanied by } \\
\text { examples and prioritizing the subject of } \\
\text { discussion } \\
\text { - Avoiding conflicting opinions on the } \\
\text { topic of conversation by not mixing up } \\
\text { the subject being discussed } \\
\text { - Avoiding interests that have nothing to } \\
\text { do with the subject matter being } \\
\text { discussed by giving opinions, } \\
\text { suggestions, or criticisms }\end{array}$ \\
\hline 6 & Sympathy & $\begin{array}{ll}\text { - } & \text { Care } \\
\text { - } & \text { Affection } \\
\text { - } & \text { Attention } \\
\text { - } & \text { Tolerant }\end{array}$ & $\begin{array}{l}\text { - Participate in feeling other people's } \\
\text { feelings in the form of congratulating } \\
\text { - Arises based on the assessment of } \\
\text { feelings from oneself to others. } \\
\text { - Refrain from negating the association } \\
\text { between people } \\
\text { - Be nice to others } \\
\text { - Skilled in understanding the feelings of } \\
\text { others. }\end{array}$ \\
\hline
\end{tabular}

\section{RESULTS AND DISCUSSION}

Based on data findings in the conversations between lecturers and students in online lectures at the Faculty of Teacher Training and Education, USN Kolaka during the Covid-19 pandemic in three study programs, namely, the Indonesian Language Education Study Program, the Physics Education Study Program, and the Geography Education Study Program, There are three languages classified by the author, namely politeness, politely, and respectful language, classified according to (Chapman, 2013; Ningsih et al., 2020; Rauf, 2017). However, based on research data, the authors found that the use of language in online learning, especially the WhatsApp application, only uses polite language because in analyzing language politely and respectfully, it cannot be identified only through online applications. After all, polite and respectful language is identical with direct behavior shown-speaker to his partner in communication (Merriam Webster Collegiate Dictionary, 1831). Thus, researchers focused on using language politeness.

After being analyzed, the researcher found (85) speeches of Leech's politeness principles with 6 maxims in three study programs. The maxims classification is in line with Leech's Theory applied in the previous research. The research from Widyaningsih \& Hastuti (2020) classified the maxim with the audio visual data. The audio-visual data is the same as WhatsApp text data collected without direct interaction. The indirect data collecting technique was applied in the Febriadina et al. (2018) listening transcript and Fitriyah et al (2020) audio record transcript.

The 6 maxims following their descriptions (18 speeches) were divided respectively in the Indonesian Language Education Study Program (12 speeches), in 
the Physics Education Study Program (4 speeches), in the Geography Education Study Program (2 speeches). The maxim of generosity (15 utterances) consists of the Indonesian Language Education Study Program (9 utterances), the Physics Education Study Program (2 utterances), and the Geography Education Study Program (4 utterances). The maxims of appreciation (15 speeches) include the Indonesian Language Education Study Program (9 speeches), the Physics Education Study Program (2 speeches), the Geography Education Study Program (4 speeches). The maxim of simplicity (3 utterances) is found in the Indonesian Language Education Study Program (1 utterance) and the Physics Study Program ( 2 utterances). Consensus maxim (26 utterances) are divided into the Indonesian Language Education Study Program (16 utterances), the Physics Education Study Program (5 utterances), and the Geography Education Study Program (5 utterances). The sympathy maxims (8 utterances) are divided into Indonesian Language Education (3 utterances), Physics Education (4 utterances) and Geography Education (1 utterance). That maxim is identified from the student and lecture chat interaction in the WhatsApp Group. The identification of the character from the students writing results was applied by previous research Kasmiati et al. (2020) Sejati et al. $(2016,2017)$ with the results of the student paper.

In this study, the researcher also found (42) violations of Leech's speech principle of politeness with 6 maxims. The violation Leech's Theory was applied in Handayani (2013) the research data collect from cellular phone. The maxims found in the Indonesian Language Education Study Program that violated the maxim of wisdom (4 utterances), the maxim of generosity (4 utterances), the maxim of appreciation (4 utterances), the maxim of simplicity (4 utterances), consensus maxim (4 utterances) and sympathy maxim (4 utterances). Physics Education Study Program that violates the maxim of wisdom ( 2 utterances), the maxim of generosity ( 2 utterances), the maxim of appreciation ( 2 utterances), the maxim of simplicity ( 2 utterances), the maxim of consensus ( 2 utterances) and the maxim of sympathy (2 utterances). Geography Education Study Program that violates the maxim of wisdom (4 utterances), the maxim of generosity (4 utterances), the maxim of appreciation (4 utterances), the maxim of consensus (4 utterances), the maxim of simplicity (4 utterances), and the maxim of sympathy (4 utterances).

First sector wisdom maxim is the first sub-sector fulfillment. The fulfillment of politeness is marked by efforts to increase the benefits for the other person or interlocutor and minimize the losses of the other person or interlocutor. Regarding the fulfillment of the principle of wisdom, 18 communication discourses show students' efforts to increase the advantage for lecturers and vice versa. The following are some forms of communication between students and lecturers that show compliance with the maxim of wisdom. According to Sejati et al. (2019) communication between students and teachers in an educative atmosphere can achieve learning goals.

[01] Lecturer: Please, sir, in the data, all active cellphone numbers are friends. Who knows there is credit assistance (D1.DM.PBI)

[02] College student: Thank you for the answer from the presenter group, the answer is very satisfying. But there is a little objection from me, namely what if there are schools that are not able to adapt to the new curriculum? As we know, many students in every school complain about changing the KTSP curriculum to curriculum 13. Is there a policy from the minister of education or the government? Or is the school allowed to return to 
the KTSP curriculum without following the government's recommendation to use curriculum 13? (D2.MM.PBI)

[14] Lecturer: Since there is a technical problem, group 3 laptops are lobed because the lights are out, the presentation is postponed until the results of the presentation of the material and the group material is sent and we start (D14.DM.FIA)

[18] Lecturer: Try editing the title, improving the example of using the environment as an outdoor-based student learning resource (D18.DM.GRI)

In conversational discourse 01 , it can be seen that the lecturer intends to ask for help from the class, which is delivered in polite language. The expression of request will have a more polite sense of value if it is conveyed with a request marked with the word "please". The value of politeness in the expression is certainly different if it is conveyed in the form of the sentence "I want to ask for data on all of his friends active cellphone numbers now!". The phrase "please" also provides comfort to the speech partner because it can make choices and there is no element of coercion or necessity so that the speech partner is not burdened and does not feel he is being ordered. In conversational discourse 02 , adherence to the principle of wisdom is indicated by the use of the words "thank you" and "very satisfactory answer". In the context of the word discourse, the use of the word "thank you" implicitly aims to give appreciation to the respected speech partner. This expression also gives comfort to the interlocutor because he feels appreciated. While the use of the word "very satisfactory answer" shows the humility of the speaker as well as a refined request. In another sense, the speaker tries to respect the interlocutor by asking for a response that allows the hearer to choose.

A similar expression is also used by lecturers in discourse 14. The fulfillment of the principle of wisdom can be seen from the information given by the speaker to the interlocutor and the opportunity for the presenter to continue the presentation when the lights in the speaker's village have turned on again. In another discourse, this study shows that there is compliance with the principle of wisdom, which is also indicated by efforts to benefit the interlocutor and provide information that does not harm others. According to Sejati et al. (2017) communication and interaction with older people must show good manner.

First sector wisdom maxim: second sub-sector violation. In the maxim of wisdom, Lecch (1993) explains that each participant of the speech must minimize the losses of others, or maximize the benefits for others (Chaer, 2010). However, the violation of the maxim of wisdom is contrary to the essence of the fulfillment of the maxim of wisdom, namely that each participant in the speech must maximize the losses of others, or minimize the benefits of others.

[01] Lecturer: It was explained that the material could not all be told to read, it had to be provoked with the presentation of the material (D1.DM.PBI)

[05] College student: One by one we don't understand. Because there has been explained what was sent in detail, so which one is the most understood (D5.MM.FIA)

[06] Lecturer: It's not like this is what was asked for.. There is a problem then there is a title.. The title does not automatically exist without a problem (D6.DM.GRI)

In speech 01, when a group discussion is about to take place, students who act as presenters of material send their material in the WhatsApp Group, but the lecturer sends speeches to students with direct speech which is considered impolite because it uses a loud tone of speech, this can be proven by The speech which states that "Please 
explain the material, you can't just read it all" the speech delivered by the lecturer seemed rushed and did not try to understand the network conditions of the student presenters, so the speech above is considered to violate the six maxims of the principle of politeness in language because it does not meet the indicators From the maxim of politeness in the Indonesian Language Education Study Program, other things that indicate a violation can be seen in speech 05 and 06 in the Department of Physics Education and the Department of Geography Education. According to Sukariasih et al. (2019) the application various method and media, such as inquiry learning could increase group activity that reduce one way communication.

Second sector generosity maxim: first sub-sector fulfillment. Fulfillment of the principle of generosity of students towards lecturers or vice versa in the discourse of communication-based on the WhatsApp social network is marked by efforts to increase losses for oneself and minimize the benefits of others. The following are some forms of communication between students and lecturers or vice versa that show adherence to the principle of generosity.

[19] Lecturer: We will assist you in the preparation of the proposal. Hopefully they will get ACC soon from their respective supervisors (D19.DM.PBI)

[20]Lecturer: For those who are guiding the problem or research title, you can go directly to your room (D20.DM.PBI)

[28] College student: Assalamu'alaikum Sorry ma'am I'm late because I just arrived in the next village because in my village there is no network and on the trip it was raining (D27.DM.FIA)

[29] Lecturer: Regarding this task, it is better to take other topics related to education so as not to make it difficult for prospective researchers (D29.DM.GRI)

In conversational discourse 19, the lecturer shows a form of generosity in his speech, which is delivered in polite language. marked with the word "we'll help later". The value of generosity in these expressions can be analyzed easily. In the conversational discourse, obedience to the principle of generosity is marked by the use of the word "may guidance in the father's room". In the word context, the discourse implicitly aims to provide a great sense of benefit to the speech partner. This expression also comforts the interlocutor because he feels very cared for. Students also use a similar expression in discourse 27. The fulfillment of the principle of generosity can be seen from the information provided by the speaker to the interlocutor who apologizes for the delay in following the course. In another discourse, this study shows that there is compliance with the principle of the maxim of generosity, which is also indicated by efforts to benefit the speech partner with greater opportunities than self-benefit. According to Amaluddin et al. (2019) the communication in the group activity sharpens physical and social students.

Second sector generosity maxim: second sub-sector violation. In the maxim of generosity Leech puts forward, make your profit as small as possible; make the loss as big as possible (Leech, 2014). If the fulfillment of the maxim of generosity states that, then the violation of the maxim of generosity is contrary to its essence, namely that the participants of the speech maximize or increase the benefits for themselves and minimize the benefits for other parties. 
WILL NOT INCLUDE THE VALUE IN SIAKAD, PLEASE CONTACT MOM IF THE VALUE DOESN'T COME OUT IN SIAKAD (D3.DM.PBI)

[05] College student: Maybe you can add more explanation about this (D5.MM.FIA)

[07] Lecturer: If it's ACC.. why don't you delete the others.. (D7.DM.GRI)

In conversational discourse 03, it occurs when the lecturer conveys the final schedule for collecting UAS assignments, if you look at the speech above the lecturer conveys using capital letters in all sentences, it shows that the lecturer uses a loud tone when the speech is spoken directly, but in online speech when read by students, the same thoughts arise when reading the article, the speech above violates the six maxims of the principle of politeness in language because the lecturer is not wise, generous, respectful, simple, agrees and sympathizes with students. This can be proven in the speech above. Thus, the speech violates the principle of politeness in language. Other conversations that show a violation can be seen in conversations 05 and 07 which give the impression of violating the principle of linguistic politeness.

Third sector appreciation maxim: first sub-sector fulfillment. According to Rahardi (2005) in the maxim of appreciation, it is explained that a person will be considered polite if, in speaking, he always tries to give appreciation to other parties. With this maxim, it is hoped that the speech participants will not mock each other, criticize each other, or demean each other.

[34] Lecturer: Please make and fill in the attendance first, so that it is clear who is entering today (D34.DM.PBI)

[36] College student: Thank you for the answer and the answer I accept (D36.MM.PBI) [42] College student: Please... but tomorrow's answer is okay, right? (D42.MM.FIA)

[44] Lecturer: I'll check back at 6. If you don't send it for a while, it means you're not present today (D44.DM.GRI)

[45] Lecturer: Regarding this task, it is better to take other topics related to education so as not to make it difficult for prospective researchers (D45.DM.GRI)

In conversational discourse 34, it can be seen that the speaking lecturer always tries to give appreciation to the other party marked by the word "please make and fill it out". The value of the maxim of appreciation in these expressions can be analyzed easily, this can be proven by conversation 36, which is marked by the use of the word "thank you" the speech shows that students in conveying their speech to other students with full appreciation, these expressions also provide comfort to the speech partner because they feel very much appreciated. Students in discourse 42 also use a similar expression. The fulfillment of the maxim of appreciation can be seen from the information given by the speaker to the speech partner, in another discourse, this study which shows the fulfillment of the principle of the maxim of appreciation is also indicated by the efforts of the speaker to the speech partner who uses speech concerning the value of appreciation high to his partner. According to Sejati et al. (2016) the student experience usually put it in their writing.

Third sector appreciation maxim: second sub-sector violation. According to Rahardi (2005) in the maxim of appreciation, it is explained that a person will be considered polite if in speaking he always tries to give appreciation to other parties. Based on this maxim, it is hoped that the speech participants will not mock each other, berate each other, or demean each other. If the fulfillment of such an award, then the violation of the maxim of appreciation is not giving awards to other parties. The speech participants mock each other, berate each other, or demean each other. Speech 
participants who often mock other speech participants in speaking activities will be said to be disrespectful people.

[04] Lecturer: As long as you are kind enough to improve your existing values (D4.DM.PBI)

[07] Lecturer: Someone already uses that title, why are you together.. don't go with your friends.. formulate it yourself (D7.DM.GRI)

The speech above occurs when the lecturer conveys about improving grades. It is clear in the speech that the lecturer maximizes praise for himself and is not generous in giving value to students who have attended online lectures by trying to find a network. The speech delivered by the lecturer indicates the existence of a violation of the principle of politeness in language due to excessive self-praise, it can be proven by the lecturer's speech which states that "As long as the mother is kind" the speech shows that the lecturer violates the principle of linguistic politeness in the maxim of wisdom, maxim of generosity, maxim of appreciation, maxim of simplicity, maxim of consensus and sympathy maxim. Another violation can also be seen in speech 07 which shows a violation of the maxim of appreciation.

Forth sector simplicity maxim: first sub-sector fulfillment. In this maxim, Leech (2014) reveals that the speech will be polite if the participant is expected to be humble by reducing praise for himself.

[47] College student: Hopefully, ma'am... there is a miracle free credit (D47.DM.PBI)

[48] College student: Sorry again, friends, the old video sent and had to be skipped because it couldn't be full (D48.MM.FIA)

[48] College student: Assalamualaikum, sorry in advance, the material for the basics is still in the process of being sent (D48.MM.FIA)

In this maxim there are only 3 utterances that meet the principle of politeness in language, in conversation 47 it can be seen that the lecturer shares information about the existence of free credit assistance by students or students, then students respond and hope that there will be free credit, this shows that there is a simple nature in students who think To be able to save costs during this online lecture, in other conversations, the maxim of simplicity can also be analyzed, which can be seen in the conversations of 48 student presenters apologizing to other students for the delay in sending videos which will be discussed because the duration of sending videos on the WhatsApp application is limited so that you have to skip the video first, the attitude of the presenter group reduces praise for himself and maximizes praise for other people or his partner, namely students and lecturers in online lecture groups. Thus, the above utterance fulfills the principle of politeness in the maxim of simplicity.

Forth sector simplicity maxim: second sub-sector violation. In the 1993 maxim of simplicity, Leech states that speech will be polite if the speech participants reduce praise to themselves and increase insults to themselves. This violation is contrary to the nature of the maxim of simplicity, namely that the speech participant cannot be humble by adding praise to himself.

In this research, the data on the violation of the maxim of simplicity is the same as the finding of the data on the maxim of wisdom, generosity, and appreciation so that the authors no longer analyze it because the data on the violation of the maxim of simplicity has been given a description of the violation of the maxim of simplicity as well. 
Fifth sector compatibility maxim, first sub-sector fulfillment. Leech (2014) said that speakers should reduce the discrepancy between self and others, and increase the congruence between self and others. In addition, Rahardi (2005) explains that in this maxim, the speech participants can foster compatibility or agreement in speaking activities.

[35] Lecturer: Use good and correct Indonesian, $z$ doesn't mean me, please fix it, this is the official forum (D35.DM.PBI)

[35] College student: Ok ma'am sorry (D35.DM.PBI)

[58] Lecturer: Just send the message and upload the paper during the presentation (D58.DM.FIA)

[58] College student: Ready ma'am (D58.DM.FIA)

[61] Lecturer: Point 1 ACC, add the concept to be taught (D61.DM.GRI)

[61] College student: Yes sir.. thank you sir (D61.DM.GRI)

In the maxim of consensus in discourse 35, it can be seen that the lecturer tells students to speak in good language in an official forum then students respond by increasing the suitability for themselves to the lecturer. Message, it can be seen that students can foster compatibility or agree on the information given by the lecturer to him. Lecturers also use a similar expression in discourse. The fulfillment of the maxim of consensus can be seen from the provision of information from speakers to the speech partner, namely the lecturer who has approved the title of the student's research. his speech. According to (Nursalam et al., 2019), there is an attempt to reach an agreement in the communication.

Fifth sector compatibility maxim: second sub-sector violation. In Leech (2014) theory, it states that speakers should reduce the discrepancy between themselves and others, and increase the congruence between themselves and others. This violation is the opposite of the essence of the maxim of consensus, namely the speaker and the speech partner minimize their agreement, and maximize their disagreement.

The findings of the violation data on the maxim of consensus are the same as the data found on the maxim of wisdom, the maxim of generosity, and the maxim of appreciation. Therefore, the researcher no longer provides information on the violation of the maxim of consensus because it has been explained in the three maxims above in the three majors that the researchers analyzed at Teacher Training and Education Faculty, USN Kolaka.

Seventh sector sympathy maxim: first sub-sector fulfillment. The sympathy maxim requires all speech participants to maximize sympathy and minimize antipathy to the interlocutor. If the interlocutor gets luck or happiness, the speaker must congratulate him. If the interlocutor gets into trouble or disaster, the speaker should express his sorrow or condolences as a sign of sympathy (Chaer, 2010).

[32] Lecturer: If anyone still survives in their boarding house and comes from outside Kolaka, please tell your mother (D32.DM.PBI)

[65]College student: It could be that the network in the village is missing (D65.DM.PBI) [69] College student: Ma'am, Hikmah's wa number has been changed, ma'am. This is the wa now ma' am (D69.DM.FIA)

[61] Lecturer: Regarding this task, it is better to take other topics related to education so as not to make it difficult for prospective researchers (D61.DM.GRI) 
[62] Lecturer: Look for other problems that do not make it difficult for prospective researchers (D62.DM.GRI)

In the conversational discourse 32, it can be seen that the lecturer shows sympathy to the students which is indicated by the word "please". The value of sympathy in this expression is very easy to analyze, the expression "please" also provides comfort to the speech partner because the speech partner. In this case, the student feels very cared for by the lecturer during this pandemic because he asks the whereabouts of students who do not return home. Fulfilling the principle of sympathy can be seen from providing information from speakers to the speech partner and providing suggestions on the topic of the research title task in speech 61. In another discourse, this study shows compliance with the principle of sympathy, which is indicated by the treatment of the speech participants who can maximize sympathy between the parties one with the other.

Seventh sector sympathy maxim: second sub-sector violation. The sympathy maxim requires that all speech participants maximize sympathy, and minimize antipathy to the interlocutor or interlocutor. If the interlocutor gets luck or happiness, the speaker is obliged to congratulate him. If the interlocutor gets into trouble or disaster, the speaker should express his sorrow or condolences as a sign of sympathy (Chaer, 2010). However, this violation is the opposite of the nature of the sympathy maxim, namely the speech participant does not maximize sympathy and does not minimize antipathy to the interlocutor.

In the sympathy maxim, the findings are the same as the three maxims above, namely the maxim of wisdom, generosity, and appreciation. Thus, the researcher no longer included the data because it had been analyzed in the three maxims above and was given a description of the similarity of the data in the maxim of sympathy.

The previous research focus on the politeness maxim in the daily activity, it did not linked or elaborated with education issue. The research Handayani (2013) focuses on violating politeness in the cellular phone provider. Some research, even focuses in movie like (Widyaningsih \& Hastuti, 2020) in the Wonderland Movie.

The research Fitriyah et al. (2020) was linked with education, and it be held in the direct classroom with one course in the English discipline. The difference of Fitriyah et al. (2020) with this research is the sum of courses and the knowledge disciplines and the way of the learning process. This research in total 3 courses in the 3 knowledge disciplines: Indonesian Language Education, Physics Education, and the Geography Education. Then the learning process in this research used online did not direct class meetings. The research Ningsih et al. (2020) is the same as (Fitriyah et al., 2020) but be held in the Senior High School.

\section{CONCLUSION}

Based on the results of research and discussion, it can be concluded that the implementation of linguistic in online lectures via WhatsApp is considered polite. That way, data from the results of research and discussion show that linguistic politeness is implemented even though lectures are conducted online. This can be proven by obtaining more fulfillment speech data than violation speech data in the research results. Thus, the implementation of linguistic politeness in online lectures is still considered a manifestation of the importance of paying attention to language etiquette directly (conventional lectures) and indirectly (online lectures). 


\section{RECOMMENDATION}

In researching the fulfillment and violations of the principle of politeness in language at Faculty of Teacher Training and Education USN Kolaka through Via WhatsApp, researchers must be thorough, focused, and careful in collecting data, selecting data, analyzing data, and classifying data. So that the data obtained regarding the fulfillment and violations of the principles of politeness in the language in the speech of online lectures between lecturers and students or students and students be precise and correct. Through this research, it is hoped that it can provide motivation and inspiration for future research that will further explore the implementation of linguistic politeness in fulfilling and violating the principles of politeness, to add sources of reference in the field of pragmatics, especially the implementation of linguistic politeness in lectures conducted online on Via WhatsApp at Faculty of Teacher Training and Education, USN Kolaka.

\section{ACKNOWLEDGMENT}

This research received no specific grant from any funding agency in the public, commercial, or not for profit sectors.

\section{REFERENCES}

Agustiani, S., Halidin, H., \& Nasruddin, N. (2020). Analisis kemampuan koneksi matematis ditinjau dari lingkungan keluarga siswa smp negeri 2 Toari. Jurnal Pendidikan Matematika, 1(2), 112-126.

Akhfar, M., \& Saputra, I. G. P. E. (2020). Efektivitas strategi elaborasi pq4r terhadap hasil belajar fisika siswa kelas vii smp negeri 7 Sinjai. JPFT (Jurnal Pendidikan Fisika Tadulako Online), 8(2).

Amaluddin, L. O., Rahmat, R., Surdin, S., Ramadhan, M. I., Hidayat, D. N., Sejati, A. E., Purwana, I. G., \& Fayanto, S. (2019). The effectiveness of outdoor learning in improving spatial intelligence. Journal for the Education of Gifted Young Scientists, 7(3), 667-680. https:// doi.org/10.17478/jegys.613987

Anhusadar, L. (2020). Persepsi mahasiswa piaud terhadap kuliah online di masa pandemi covid 19. KINDERGARTEN: Journal of Islamic Early Childhood Education, 3(1), 44-58. https:/ / doi.org/10.24014/KJIECE.V3I1.9609

Anhusadar, L. O. (2020). Persepsi mahasiswa piaud terhadap kuliah online di masa pandemi. KINDERGARTEN: Journal of Islamic Early Childhood Education, 3(1), 4458. https:/ / doi.org/10.24014/KJIECE.V3I1.9609

Apuke, O. D., \& Iyendo, T. O. (2018). University students' usage of the internet resources for research and learning: forms of access and perceptions of utility. Heliyon, 4(12), 1-34. https:/ / doi.org/10.1016/j.heliyon.2018.e01052

Chaer, A. (2010). Language Politeness. Jakarta: Rineka Cipta.

Chapman, L. M. (2013). Respectful language. Journal of Psychological Issues in Organizational Culture, 3(S1), 115-132. https://doi.org/10.1002/JPOC.21103

Damhuri, D., Sejati, A. E., \& Hidayati, D. N. (2018). Adaptation of farmers in rice cultivation at dry season in gunungsari village (Bojonegoro-East Java) for learning source. Proceedings of the UR International Conference on Educational Sciences, $0(0)$, 93-99. https:/ / ejournal.unri.ac.id/index.php/ICES/article/view/4737

Djidu, H., \& Retnawati, H. (2018). Cultural values-integrated mathematical learning model to develop HOTS and character values. In E. Retnowati, A. Ghufron, 
Marzuki, Kasiyan, A. C. Pierawan, \& Ashadi (Eds.), Character Education for 21st Century Global Citizens (pp. 363-370). Routledge. https:/ / doi.org/10.1201/9781315104188-46

Emda, A. (2017). Laboratorium sebagai Sarana Pembelajaran Kimia dalam Meningkatkan Pengetahuan dan Ketrampilan Kerja Ilmiah. Lantanida Journal, 2(2), 218. https:/ / doi.org/10.22373/lj.v2i2.1409

Febriadina, Z. F., Sumarwati, S., \& Sumarlam, S. (2018). Male and female students' politeness in Sragen, Central Java. Humanus, 17(1), 73-83. https://doi.org/10.24036/humanus.v17i1.8429

Fitriyah, F., Dewi, N., Putra, O. P., \& Sulistyawati, M. E. S. (2020). Lecturers' politeness strategies and students' compliance in english for foreign language (efl) class. Language Literacy: Journal of Linguistics, Literature, and Language Teaching, 4(1), 7591. https:// doi.org/10.30743/LL.V4I1.2463

Halil, N. I. (2020). The effectiveness of using edmodo as an online learning platform in covid-19. Jurnal Penelitian Dan Pengkajian Ilmu Pendidikan: E-Saintika, 4(3), 284298. https:// doi.org/10.36312/E-SAINTIKA.V4I3.316

Handayani, T. (2013). Violating politeness principles in cellular phone provider lantern. Journal on English Language, Culture and Literature, 2(3), 293-303. https:/ / ejournal3.undip.ac.id/index.php/engliterature/article/view/3366

Harianto, E., Nursalam, L. O., Ikhsan, F. A., Zakaria, Z., Damhuri, D., \& Sejati, A. E. (2019). The compatibility of outdoor study application of environmental subject using psychological theories of intelligence and meaningful learning in senior high school. Geosfera Indonesia, 4(2), 201-216. https:/ / doi.org/10.19184/geosi.v4i2.9903

Hassan, A. Q. A., \& Ahmed, S. S. (2018). The impact of whatsapp on learners' achievement: a case study of english language majors at King Khalid University. International Journal of English Language Education, 6(2), 69-81. https://doi.org/10.5296/ijele.v6i2.13743

HL, N. I., Saputra, I. G. P. ., \& Sejati, A. . (2020). Developing teaching material bajo's local wisdom sea preservation Thomson-Brooks/Cole model. JPI, 9(3), 355-367. https:/ / doi.org/10.23887/jpi-undiksha.v9i3.23234

Hunaidah, M., Sukariasih, L., \& Saputra, I. G. P. E. (2019). Penerapan model pembelajaran discovery untuk meningkatkan keterampilan proses sains dan penguasaan konsep ipa peserta didik kelas viiid smp kartika XX-6 Kendari. JPFT (Jurnal Pendidikan Fisika Tadulako Online), 7(3).

Jahring, J., Nasruddin, N., \& Farida, I. (2020). The effectiveness of mind mapping Learning models based on contextual learning on mathematical problem solving ability. Proceeding of USN Kolaka-ADRI International Conference on Sustainable Coastal-Community Development, 1, 189-193. https://doi.org/10.31327/icusnadri.v1i0.1177

Kasmiati, S., Purbaningsih, Y., Hasan, M., Sejati, A. E., \& Chairuddin, C. (2020). The effect basic training to student's environmental awareness character. Proceeding of USN Kolaka-ADRI International Conference on Sustainable Coastal-Community Development, 1(0), 64-68. https:/ / doi.org/10.31327/ICUSN-ADRI.V1I0.1140

Khasanah, D. R. A. U., Pramudibyanto, H., \& Widuroyekti, B. (2020). Pendidikan dalam masa pandemi covid-19. Jurnal Sinestesia, 10(1), 41-48.

Kusmana, A. (2011). E-learning dalam pembelajaran. Lentera Pendidikan: Jurnal Ilmu Tarbiyah Dan Keguruan, 14(1), 35-51. https:/ / doi.org/10.24252/1p.2011v14n1a3 
Leech, G. N. (2014). The Pragmatics of Politeness. Oxford University Press. https:/ / books.google.co.id/books?hl=en\&lr=\&id=cCyTAwAAQBAJ\&oi=fnd\& pg=PP1\&dq=info:Rz-

E2lxmUOcJ:scholar.google.com\&ots=QNX8QUgJDX\&sig=ixL7i_yQBccETFgN

GI91cMKGMvw\&redir_esc=y\#v=onepage\&q\&f=false

Moleong, L. J. (2014). Metodologi Penelitian Kualitatif Edisi Revisi. PT. Remaja Rosdakarya.

Ningsih, R., Boeriswati, E., \& Muliastuti, L. (2020). Language politeness of students and teachers: An ethnographic study. Getsempena English Education Journal , 7(1), 159-169. https://doi.org/10.46244/GEEJ.V7I1.1063

Nurdin, E. A., Ikhsan, F. A., Kurnianto, F. A., \& Apriyanto, B. (2017). Application of contextual teaching learning to learning results in understanding the life environment in smp negeri 2 Sukodono. Geosfera Indonesia, 1(1), 13. https:/ / doi.org/10.19184/geosi.v1i1.6189

Nursalam, L. O., Harianto, E., Hasan, M., \& Sejati, A. E. (2019). Nilai-nilai dalam aktualisasi peningkatan karakter kepedulian lingkungan mahasiswa. Tunas Geografi, 8(2), 151-160. https:// doi.org/10.24114/tgeo.v8i2.17190

Nurul H., D., Amaluddin, L. O., \& Surdin, S. (2017). The effect guided inquiry to critical thinking ability to build student character in geography subject. 1st International Conference on Geography and Education (ICGE 2016), 367-371. https:/ / doi.org/10.2991/icge-16.2017.71

Prajana, A. (2017). Pemanfaatan aplikasi whatsapp untuk media pembelajaran dalam lingkungan uin Ar-Raniry Banda Aceh. Cyberspace: Jurnal Pendidikan Teknologi Informasi, 1(2), 122. https://doi.org/10.22373/cs.v1i2.1980

Putria, H., Maula, L. H., \& Uswatun, D. A. (2020). Analisis proses pembelajaran dalam jaringan (daring) masa pandemi covid- 19 pada guru sekolah dasar. Jurnal Basicedu, 4(4), 861-870. https:/ / doi.org/10.31004/basicedu.v4i4.460

Rahardi, Kunjana. 2005. Pragmatics: Indonesian Imperative Politeness. Jakarta: General Erlangga

Rahmawati, F. (2016). E-Learning implementation: its opportunities and drawbacks perceived by efl students. Journal of Foreign Languange Teaching and Learning, 1(1), 1-15. https://doi.org/10.18196/ftl.111

Rauf, M. (2017). Polite expressions used by teachers in teaching english in the classroom. English and Literature Journal, 2(1), 139-157. http://journal.uinalauddin.ac.id/index.php/elite/article/view/3388

Rukiyati, R. (2019). Tujuan pendidikan nasional dalam perspektif Pancasila. Humanika, Kajian Ilmiah Mata Kuliah Umum, 19(1), 56-69. https:/ / doi.org/10.21831/HUM.V19I1.30160

Saifuddin, M. F. (2018). E-Learning dalam persepsi mahasiswa. Jurnal VARIDIKA, 29(2), 102-109. https:// doi.org/10.23917/varidika.v29i2.5637

Saputra, I. G. P. E. (2020). Penguasaan konsep fisika siswa menggunakan pendekatan konflik kognitif pada materi gerak lurus di smk negeri 2 Watubangga. JPFT (Jurnal Pendidikan Fisika Tadulako Online), 8(3).

Scott, M. R. (2008). Principles of Pragmatics G. N. Leech. Ilha Do Desterro, 5(11), $123-$ 129. https://www.researchgate.net/publication/49617979_G_N_LEECH__Principles_of_Pragmatics_G_N_LEECH_-_Principles_of_Pragmatics

Sejati, A. E., Kasmiati, S., \& Ikhsan, F. A. (2019). The relationship between learning process interactions and student's learning outcomes in environmental 
sustainability matter geography-social science education subject. IOP Conference Series: Earth and Environmental Science, 282(2019), 012026. https:/ / doi.org/10.1088/1755-1315/382/1/012026

Sejati, A. E., Amaluddin, L. O., Hidayati, D. N., Kasmiati, S., Sumarmi, S., \& Ruja, I. N. (2017). The effect of outdoor study on the geography scientific paper writing ability to construct student character in senior high school. Proceedings of the 5 th SEA-DR (South East Asia Development Research) International Conference 2017 (SEADRIC 2017), 104-108. https:/ / doi.org/10.2991/seadric-17.2017.22

Sejati, A. E., Nasarudin, N., \& Ikhsan, F. A. (2020). The effect outdoor study to the students activeness in senior high school. Geographica, 1(1), 7-12. http:// usnsj.com/index.php/geographica/article/view/1016

Sejati, A. E., Sumarmi, S., \& Ruja, I. N. (2016a). Pengaruh metode pembelajaran outdoor study terhadap kemampuan menulis karya ilmiah geografi untuk meningkatkan karakter cinta lingkungan. Prosising Nasional Fakultas Ilmu Sosial, Universitas Negeri Malang. https:/ / scholar.google.com/scholar?cluster=3317211790805227355\&hl=en\&oi= scholarr

Sejati, A. E., Sumarmi, S., \& Ruja, I. N. (2016b). Pengaruh metode pembelajaran outdoor study terhadap kemampuan menulis karya ilmiah geografi sma. Jurnal Pendidikan: Teori, Penelitian, Dan Pengembangan, 1(2), 80-86. https:/ / doi.org/10.17977/JP.V1I2.5804

Sujana, I. W. C. (2019). Fungsi dan tujuan pendidikan Indonesia. Adi Widya: Jurnal Pendidikan Dasar, 4(1), 29-39. https:/ / doi.org/10.25078/aw.v4i1.927

Sukariasih, L., Sahara, L., Reskiawan, B., \& Nursalam, L. O. (2019). Improving the Skill of Physics Science Process through Guide Discovery Method in Students at Senior High School.

Sukariasih, L., Saputra, I. G. P. E., Ikhsan, F. A., Sejati, A. E., \& Nisa, K. (2019). Improving the learning outcomes of knowledge and inquiry skill domain on third grade students of smp negeri 14 Kendari through the guided inquiry learning model assisted by science kit. Geosfera Indonesia, 4(2), 175-187. https://doi.org/10.19184/geosi.v4i2.10097

Supariani, N. K. D., Rinda, R., Herlianti, R., \& Djidu, H. (2021). Kendala dalam pembelajaran daring. EDUMATIC: Jurnal Pendidikan Matematika, 2(1), 17-23.

Thelwall, M., \& Thelwall, S. (2020). Retweeting for COVID-19: Consensus building, information sharing, dissent, and lockdown life. http:/ / arxiv.org/abs/2004.02793

Thornton, J. (2020). Covid-19: A\&E visits in England fall by $25 \%$ in week after lockdown. BMJ (Clinical Research Ed.), 369, m1401. https:/ / doi.org/10.1136/bmj.m1401

Wibawa, R. P., Astuti, R. I., \& Pangestu, B. A. (2019). Smartphone-based application "quizizz" as a learning media. Dinamika Pendidikan, 14(2), 244-253. https:/ / doi.org/10.15294/dp.v14i2.23359

Widyaningsih, M., \& Hastuti, E. (2020). Maxims of politeness on alice in wonderland movie (Pragmatic analysis). Journal of Language and Literature, 6(2), 64-71. https:/ / doi.org/10.35760/JLL.2018.V6I2.2484 